\title{
Associations between plant and animal protein intake and anthropometric indices among school-aged girls in Kabul Afghanistan
}

\author{
Fawzia Zahidi ${ }^{1}$, Mohammad Ashraf Farahmand ${ }^{2}$, Mursal Basiry ${ }^{3}$, Madiha Khalid ${ }^{4}$, Pamela \\ Surkan $^{5}$, and Leila Azadbakht ${ }^{2}$ \\ ${ }^{1}$ Affiliation not available \\ ${ }^{2}$ Tehran University of Medical Sciences \\ ${ }^{3}$ Tehran University of Medical Sciences School of Nutritional Sciences and Dietetics \\ ${ }^{4}$ Tehran University of Medical Sciences School of Pharmacy \\ ${ }^{5}$ Johns Hopkins University Bloomberg School of Public Health
}

September 24, 2021

\begin{abstract}
Background: Adolescent girls in Afghanistan have high levels of food insecurity, yet little is known about their dietary intakes. Therefore, we aimed to study the association between dietary protein intake and anthropometric indices among adolescent girls in Kabul, Afghanistan. Methods: We conducted a cross-sectional study of 380 adolescent girls at 16 government schools from eight randomly sampled zones in Kabul. In July 2019, we assessed dietary intake, body mass index (BMI), physical activity and socio-demographic variables. Binary logistic regression models were used to estimate the associations between different protein sources (plant protein, animal protein and total protein) and stunting, wasting, overweight and obesity. Results: Participant mean age was $14.8 \pm 2$ years and mean BMI was $19.8 \pm 3.6 \mathrm{~kg} / \mathrm{m} 2$. The mean intakes of carbohydrates from plant proteins, animal proteins and total proteins were approximately $59.4 \pm 19.6 \mathrm{gr} /$ day, $22.3 \pm 7.3 \mathrm{gr} /$ day and $81.8 \pm 27.1 \mathrm{gr} /$ day, respectively. Students with more highly educated fathers consumed more plant proteins $(\mathrm{P}<0.05)$. Participants had overall high dietary plant protein intake (mean $34.8 \pm 22.0 \mathrm{~g} /$ day), with $66 \%$ from grains, cereals and flour. We did not find an association between dietary protein intake and stunting ( $\mathrm{OR}=0.92$; CI: 0.55-1.54), wasting ( $\mathrm{OR}=0.98$; CI: 0.55-1.78), overweight (OR=1.18; CI: 0.62-2.25) or obesity ( $\mathrm{OR}=0.84$; CI: 0.19-3.58). Conclusion: While prior research suggests that dietary protein intake is associated with improved nutritional and anthropometric indices, dietary protein intake in this study was not associated with stunting, wasting, overweight and obesity. Further investigation is needed on this topic.
\end{abstract}

\section{Hosted file}

Main file_Fawzia_proteins_JS.docx available at https://authorea.com/users/435172/articles/ 538375-associations-between-plant-and-animal-protein-intake-and-anthropometric-indicesamong-school-aged-girls-in-kabul-afghanistan 